\title{
Reducing Heavy Metal Element from Coal Bottom Ash by Using Citric Acid Leaching Treatment
}

\author{
Ahmad Asyari Yahya ${ }^{1}$, Noorwirdawati Ali ${ }^{1, *}$, Nur Liyana Mohd Kamal ${ }^{2}$, Shahiron \\ Shahidan $^{1}$, Salmia Beddu ${ }^{2}$, Muhd. Fadhil Nuruddin ${ }^{3}$, and Nasir Shafiq ${ }^{3}$ \\ ${ }^{1}$ Jamilus Research Center, Faculty of Civil and Environmental Engineering, Universiti Tun Hussein \\ Onn Malaysia, Malaysia \\ ${ }^{2}$ Civil Engineering Department, Universiti Tenaga Nasional, Malaysia \\ ${ }^{3}$ Civil \& Environmental Engineering Department, Universiti Teknologi Petronas, Malaysia
}

\begin{abstract}
Coal ash is the residue that is produced during coal combustion for instance fly ash, bottom ash or boiler slag which was primarily produced from the combustion of coal. With growth in coal burning power station, huge amount of coal bottom ash (CBA) considered as hazardous material which are normally disposed in an on-site disposal system without any commercialization purpose. Previous researchers have studied the extraction of silica from agricultural wastes such as palm ash and rice husk ash (RHA) and CBA by using leaching treatment method. In this study, the weaker acid, citric acid solution was used to replace the strong acid in leaching treatment process. Result showed that the heavy metal content such as Copper $(\mathrm{Cu})$, Zinc $(\mathrm{Zn})$ and Lead $(\mathrm{Pb})$ can be decrease. Meanwhile the silica can be extracted up to $44 \%$ from coal bottom ash using citric acid leaching treatment under the optimum reaction time of 60 minutes with solution temperature of $60^{\circ} \mathrm{C}$ and concentration of citric acid more than $2 \%$.
\end{abstract}

\section{Introduction}

Coal bottom ash has a potential to be used in industry. Instead of dumping, the physical and chemical properties of CBA shows that it could be used as a possible applications including as cement replacement, ceramic products and construction materials [1-3]. Previous researchers have proved the existence of silica as a major compound and heavy metal impurities in coal bottom ash [4-5] and therefore, there is a possibility to extract silica from coal bottom ash and at the same time reducing the heavy metal element in coal bottom ash.

Silicon dioxide also known as silica is one of the basic material and the valuable inorganic multipurpose chemical compound. Normally, silica naturally occurred as quartz, sand or flint. It can exist either in gel, crystalline or amorphous forms. It is the most abundant material on the earth's crust. Nowadays, extraction process was used to produce

\footnotetext{
*Corresponding author: wirda@uthm.edu.my
} 
silica from quartz or sand Sodium silicate, the precursor for silica production is currently manufactured by smelting quartz sand with sodium carbonate at $1300^{\circ} \mathrm{C}[6]$.

It is also found that the metallic element such as Copper(Cu), Nickel(Ni), Chromium(Cr), Zinc( $\mathrm{Zn})$ and $\operatorname{Lead}(\mathrm{Pb})[7,8]$ resulting the classification of CBA in Malaysia under the Schedule Waste (SW 104) Environment Quality Act [9]. Even though the utilization of CBA have been practice with positive result, but weathering and erosion over time will cause the heavy metal to leach out. The existence of those elements in the ash could pollute the environment and pose a danger to public health [10] and therefore, an effective treatment need to be done to overcome the problem.

Leaching treatment show a potential route in silica extraction and reducing heavy metal compound. From previous research, strong acid such as sulphuric acid $\left(\mathrm{H}_{2} \mathrm{SO}_{4}\right)$, hydrochloric acid (HCL) and nitric acid $\left(\mathrm{HNO}_{3}\right)$ solution were used conventionally in leaching treatment in extraction of silica material $[7,11]$ Other than that, sodium oxide $(\mathrm{NaOH})$ and ammonium citrate solution were also being used in leaching treatment as a silica extraction and to reduce the heavy metal impurities [8, 12]. However, these leaching agents is hazardous to environment and human, the strong acid leaching treatment also had an economic problems since the materials are expensive due to the corrosion resistance to strong acid and special disposal treatment of used strong acid.

The objective of this study was to study the possibility in developing new method in extracting silica compound and reducing heavy metal element by using citric acid leaching method.

\section{Materials: Coal bottom ash}

Tanjung Bin is one of power plant in Malaysia that used coal to produce electricity. It has been reported that, Tanjung Bin power plant needs about 18000 ton/ day of coal to generate electricity [13]. Coal bottom ash is one of the example of the coal waste product that are produced by the Tanjung Bin power plant. Due to the large volume of waste material, the large quantity of coal ash will be considerable disposal concern because of the increase requirement for ash storage space. Hence, this will increase the expanses to obtain larger area $[13,14]$ and it could lead to the environmental problem to the future [7]. Table 1 shows that CBA has about $41 \%$ of silicon element and the list heavy metal element that exist in coal bottom ash.

Table 1. Chemical composition of untreated CBA.

\begin{tabular}{|c|c|}
\hline Compound & Concentration (\%) \\
\hline $\mathrm{SiO}_{2}$ & 41.10 \\
\hline $\mathrm{Al}_{2} \mathrm{O}_{3}$ & 14.20 \\
\hline $\mathrm{Fe}_{2} \mathrm{O}_{3}$ & 6.88 \\
\hline $\mathrm{Pb}$ & 0.0031 \\
\hline $\mathrm{Cu}$ & 0.0103 \\
\hline $\mathrm{Ni}$ & 0.0015 \\
\hline $\mathrm{Zn}$ & 0.0267 \\
\hline $\mathrm{Cr}$ & 0.0034 \\
\hline
\end{tabular}




\section{Method and procedures: Leaching process}

Generally, leaching refers to the disposal of substance from a solid via a liquid extraction media. The desired component diffuses into the solvent from its natural solid form. In leaching process, there are three important parameters which are temperature, contact time per area and selection of solvent. In order to obtain an optimized solubility and mass transfer, the temperature was adjusted accordingly. There are two categories in leaching which are percolation and solid dispersed. Usually, the solid was crushed into small pieces before being contacted with solvent.

Coal bottom ash that was collected from Tanjung bin power plant was used as raw material to produce silica material and eliminating heavy metal compound. Previous research clarified that the citric acid solution leaching treatment can increase the silica content for palm ash [11] while the heavy metal content can be reduce by extraction and leaching treatment [15].

$40 \mathrm{~g}$ coal bottom ash with average particle size of $75 \mu \mathrm{m}$ was put into $1000 \mathrm{~mL}$ beaker that contained citric acid solution. The beaker was placed on the hot plate magnetic stirrer as shown in Fig. 1. The concentration and temperature of the citric acid solution were selected as the operating parameter. The concentration was controlled from $2 \%$ to $5 \%$ by changing the mixing ratio between citric acid powder (EMORY, Purity $\geq 99.5 \%$ ) and distilled water.

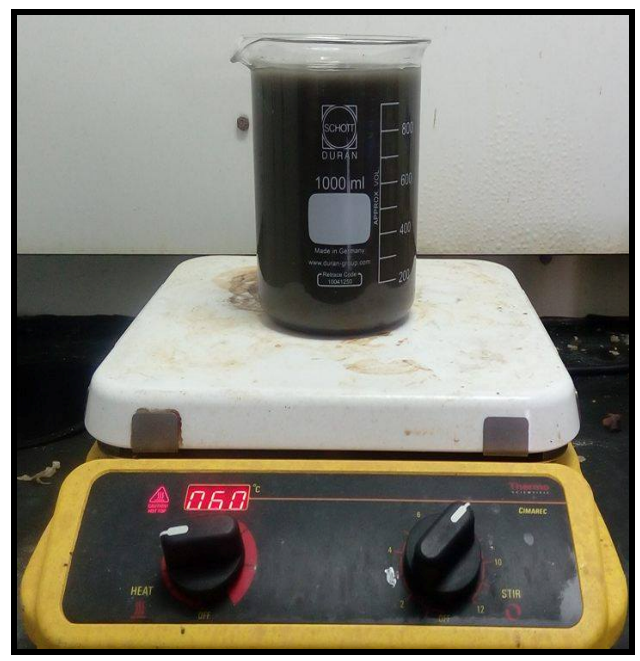

Fig. 1. Heating and stirring process in CBA leaching treatment.

The solution temperature was changed from $30^{\circ} \mathrm{C}$ to $70^{\circ} \mathrm{C}$ with reaction time recorded within 60 minutes. After the acid leaching process, the water rinsing treatment of coal bottom ash was conducted with distilled water at room temperature that functions as a removal of excessive citric acid content in the ash as shown in Fig. 2.

The ash then was filtered by using vacuum filtered (GAST, MODEL:DOA-P504-BN) as shown in Fig. 3 to obtain the retained treated ash. After that, the ash was dried at $60^{\circ} \mathrm{C}$ for 60 minutes in the oven. It was then combusted at $800^{\circ} \mathrm{C}$ for 30 minutes in the furnace (Carbolite HTF Furnace, Model 1800). The airflow rate in the combustion was set to 2 $\mathrm{ml} / \mathrm{s}$. Then, the treated ash containing metallic compound was tested by using X-ray fluorescence spectroscopy ( Model XRF BRUKER S4 PIONEER). 


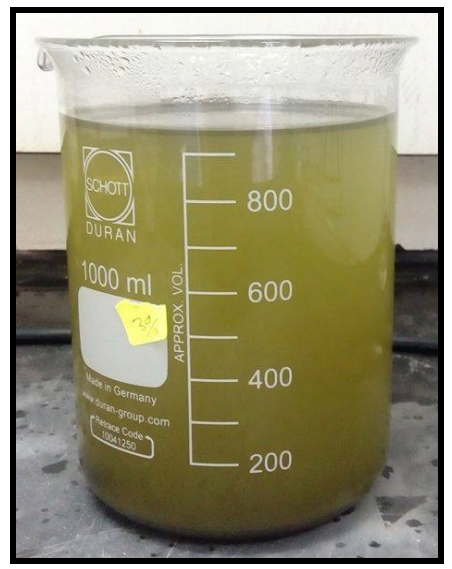

Fig. 2. Water rinsing treatment at room temperature.

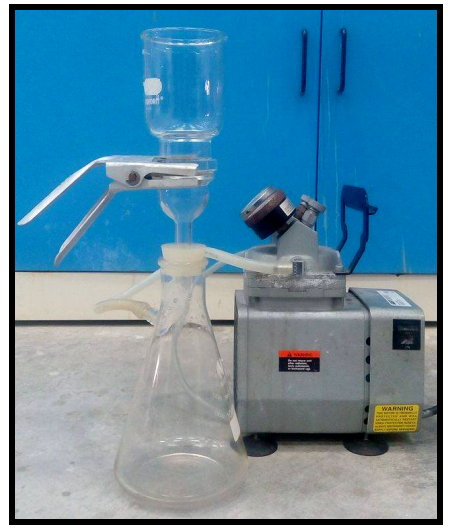

Fig. 3. Image of vacuum filtered (GAST, MODEL: DOA-P504-BN).

\section{Results and discussions}

In this study, citric acid seems to be as a good alternative to substitute strong acid in leaching process since citric acid reacted as an organic acid which it has less hazardous effect compared to the stronger acid usage. The data was analyses by comparing the result with untreated CBA as shown in table 1. Temperature, time and selection of solvent acted as an important parameter that was considerate in leaching process.

\subsection{The effect of solution temperature}

Table 2 shows the chemical composition of coal bottom ash after leaching treatment was done under different solution temperature. Some researchers had done leaching experiments at ambient temperature. From the result, the temperature tends to vaporize organic acids and water [16]. The use of high temperature can increase the leaching performance but the use of organic acid with high temperature seen to be limited due to low boiling temperature and decomposition of citric acid. Experimental result from table 2 shows that the metallic content for $\mathrm{Pb}, \mathrm{Cu}$, and $\mathrm{Zn}$ shows some decrement compared to the untreated $\mathrm{CBA}$ specimen. The higher the temperature, the more the percentage of heavy metal was leached 
out. However, the percentage of $\mathrm{Ni}$ and $\mathrm{Cr}$ show some increment when higher temperature was used. The silicon oxide $\left(\mathrm{SiO}_{2}\right)$ content of treated $\mathrm{CBA}$ increase up to $44.5 \%$. Moreover, the result from table 3 shows the some fluctuation value for the metallic content in treated CBA and the $\mathrm{SiO}_{2}$ content was increased up to $43 \%$ compared to control specimen.

Table 2. The chemical composition of coal bottom ash treated with $2 \%$ citric acid by leaching treatment with difference solution temperature.

\begin{tabular}{|c|c|c|c|c|c|c|c|c|}
\hline $\begin{array}{c}\text { Solution } \\
\text { tempera- } \\
\text { ture } \\
\left.\mathbf{(}^{\mathbf{0}} \mathbf{C}\right)\end{array}$ & $\mathbf{S i o}_{\mathbf{2}}$ & $\mathbf{A l}_{\mathbf{2}} \mathbf{O}_{\mathbf{3}}$ & $\mathbf{F e}_{\mathbf{2}} \mathbf{O}_{\mathbf{3}}$ & $\mathbf{P b}$ & $\mathbf{C u}$ & $\mathbf{N i}$ & $\mathbf{Z n}$ & $\mathbf{C r}$ \\
\hline $30^{\circ} \mathrm{C}$ & 39.90 & 15.20 & 7.16 & 0.0027 & 0.0063 & 0.0077 & 0.0055 & 0.0090 \\
\hline $40^{\circ} \mathrm{C}$ & 39.50 & 14.60 & 6.88 & 0.0028 & 0.0062 & 0.0131 & 0.0048 & 0.0514 \\
\hline $50^{\circ} \mathrm{C}$ & 39.30 & 14.50 & 7.77 & 0.0026 & 0.0060 & 0.0126 & 0.0047 & 0.0383 \\
\hline $60^{\circ} \mathrm{C}$ & 44.50 & 15.40 & 6.10 & 0.0018 & 0.0058 & 0.0073 & 0.0068 & 0.0450 \\
\hline $\begin{array}{c}\text { Untreated } \\
\text { CBA }\end{array}$ & 41.10 & 14.20 & 6.88 & 0.0031 & 0.0103 & 0.0015 & 0.0267 & 0.0034 \\
\hline & $\begin{array}{c}\text { increa } \\
\text {-se }\end{array}$ & increase & $\begin{array}{c}\text { mode- } \\
\text { rate }\end{array}$ & decrease & decrease & increase & decrease & $\begin{array}{c}\text { incre- } \\
\text { ase }\end{array}$ \\
\hline
\end{tabular}

Table 3. The chemical composition of coal bottom ash treated with $3 \%$ citric acid by leaching treatment with difference solution temperature.

\begin{tabular}{|c|c|c|c|c|c|c|c|c|}
\hline $\begin{array}{c}\text { Solution } \\
\text { tempera- } \\
\text { ture } \\
\left({ }^{\mathbf{0}} \mathbf{C}\right)\end{array}$ & $\mathbf{S i o}_{\mathbf{2}}$ & $\mathbf{A l}_{\mathbf{2}} \mathbf{O}_{\mathbf{3}}$ & $\mathbf{F e}_{\mathbf{2}} \mathbf{O}_{\mathbf{3}}$ & $\mathbf{P b}$ & $\mathbf{C u}$ & $\mathbf{N i}$ & $\mathbf{Z n}$ & $\mathbf{C r}$ \\
\hline $30^{\circ} \mathrm{C}$ & 42.60 & 14.40 & 6.07 & 0.0015 & 0.0056 & 0.0068 & 0.0062 & 0.0096 \\
\hline $40^{\circ} \mathrm{C}$ & 42.20 & 14.20 & 6.17 & 0.0013 & 0.0054 & 0.0069 & 0.0059 & 0.0171 \\
\hline $50^{\circ} \mathrm{C}$ & 40.80 & 15.20 & 7.17 & 0.0025 & 0.0059 & 0.0118 & 0.0046 & 0.0357 \\
\hline $60^{\circ} \mathrm{C}$ & 43.40 & 14.90 & 5.95 & 0.0017 & 0.0055 & 0.0072 & 0.0066 & 0.0113 \\
\hline $\begin{array}{c}\text { Untreated } \\
\text { CBA }\end{array}$ & 41.10 & 14.20 & 6.88 & 0.0031 & 0.0103 & 0.0015 & 0.0267 & 0.0034 \\
\hline & $\begin{array}{c}\text { incre- } \\
\text { ase }\end{array}$ & moderate & decrease & decrease & decrease & increase & decrease & increase \\
\hline
\end{tabular}

\subsection{The effect of solvent with acid solution}

The reaction between solvent and acid solution is an important factor in order to achieve a good result in leaching treatment. Table 4 shows the chemical composition of coal bottom ash after being treated via citric acid solution treatment with different concentration. The temperature of citric acid solution was fixed at $60^{\circ} \mathrm{C}$ with reaction time of 60 minutes. From the experimental result at table 6 , it shows that the purity of silica $\left(\mathrm{SiO}_{2}\right)$ of bottom ash increased about $43 \%$ when citric acid solutions were employed with a concentration of $2 \%$ and higher. The heavy metal impurities such as $\mathrm{Pb}, \mathrm{Cu}$ and $\mathrm{Zn}$ show some decrement when the citric acid concentration was increased.

Thus, its shows that citric acid leaching treatment was essential in order to increase the purity of silica $\left(\mathrm{SiO}_{2}\right)$ in bottom ash. The percentage of $\mathrm{Al}_{2} \mathrm{O}_{3}$ compound also seems to be increased compared to untreated CBA sample although the percentage of $\mathrm{Al}_{2} \mathrm{O}_{3}$ compound decrease with increasing of acid concentration. Apart from that, the leaching treatment help to reduce the heavy metal impurities content compared to untreated CBA except for Ni and 
$\mathrm{Cr}$ element. The increasing percentage of $\mathrm{Cr}$ and $\mathrm{Ni}$ may be due to the lack of time reaction during leaching treatment. The color of pulverized coal bottom ash after citric acid leaching treatment was changed from dark grey to brown color as shown in Fig. 3.

Table 4. Chemical composition of coal bottom ash treated with difference concentration of citric acid with temperature of $60^{\circ} \mathrm{C}$.

\begin{tabular}{|c|c|c|c|c|c|c|c|c|}
\hline $\begin{array}{c}\text { Acid } \\
\text { Concen } \\
\text { tration } \\
(\%)\end{array}$ & $\mathbf{S i O}_{\mathbf{2}}$ & $\mathrm{Al}_{\mathbf{2}} \mathbf{O}_{\mathbf{3}}$ & $\mathbf{F e}_{\mathbf{2}} \mathbf{O}_{\mathbf{3}}$ & $\mathbf{P b}$ & $\mathbf{C u}$ & $\mathbf{N i}$ & $\mathbf{Z n}$ & $\mathbf{C r}$ \\
\hline 2 & 44.50 & 15.40 & 6.10 & 0.0018 & 0.0058 & 0.0073 & $\begin{array}{c}0.006 \\
8\end{array}$ & $\begin{array}{c}0.045 \\
0\end{array}$ \\
\hline 3 & 43.40 & 14.90 & 5.95 & 0.0017 & 0.0055 & 0.0072 & $\begin{array}{c}0.006 \\
6\end{array}$ & $\begin{array}{c}0.011 \\
3\end{array}$ \\
\hline $\begin{array}{c}\text { Untrea- } \\
\text { ted } \\
\text { CBA }\end{array}$ & 41.10 & 14.20 & 6.88 & 0.0031 & 0.0103 & 0.0015 & $\begin{array}{c}0.026 \\
7\end{array}$ & $\begin{array}{c}0.003 \\
4\end{array}$ \\
\hline & increase & increase & decrease & decrease & decrease & increase & $\begin{array}{c}\text { decrea } \\
\text { se }\end{array}$ & $\begin{array}{c}\text { increa } \\
\text { se }\end{array}$ \\
\hline
\end{tabular}

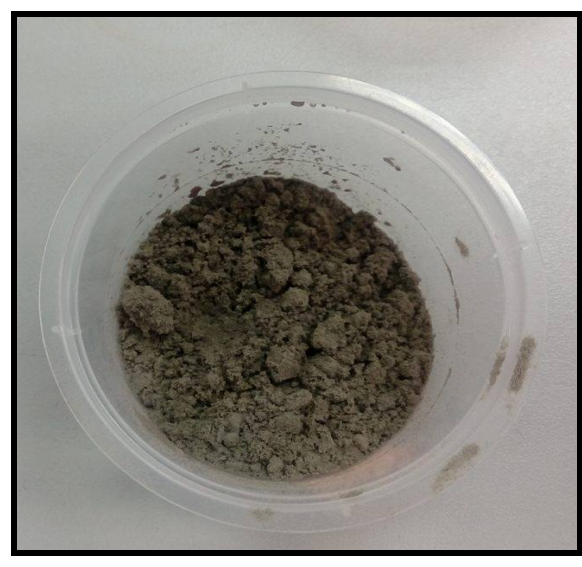

(a)

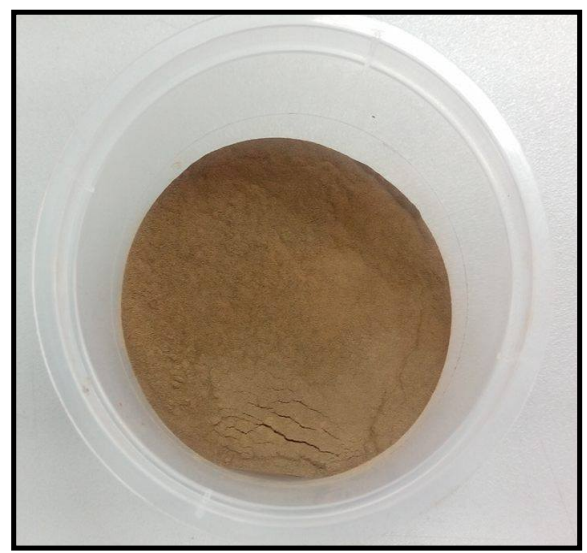

(b)

Fig. 3. Image of coal bottom ash (a) before leaching treatment (b) after leaching treatment.

\section{Conclusions}

The experimental studies show that there is a possibility to extract silica and at the same time reduce the heavy metal impurities except for $\mathrm{Cr}$ and Ni from CBA by using acid leaching method. This could be due to the effect of less time reaction of the treatment. From the result, it shows that the purity of silica was increased up to $43 \%$ with the increasing of acid concentration under extracting temperature of $60^{\circ} \mathrm{C}$ and optimum reaction time of 60 minutes. Moreover, although the metallic content for $\mathrm{Pb}, \mathrm{Cu}$ and $\mathrm{Zn}$ are not fully eliminated, but it can be reduce with higher concentration and temperature. But, for the metallic content of $\mathrm{Cr}$ and $\mathrm{Ni}$, further studies need to be done to determine the efficient factor of leaching treatment on eliminating the element. Therefore, it can be conclude that by increasing the acid concentration and temperature of the solution may lead to the better result. 
This research was supported by Postgraduate Research Grant under Office of Research, Innovation, Commerlization, Consultancy management (ORICC), Universiti Tun Hussein Onn Malaysia (Project Vote No: U444) and Fundamental Research Grant Scheme (FRGS) by Minister of Higher Education (Vote No: FRGS/1/2015/TK06/UNITEN/03/2).

\section{References}

[1] S.O. Bada and S. Potgieter-Vermaak, Evaluation and treatment of coal fly ash for adsorption application, Leonardo Electronic J. of Practices and Technologies, 37-48, (2008)

[2] M. Cheriaf, J. C. Rocha, and J. Péra, Pozzolanic properties of pulverized coal combustion bottom ash, Cem. Concr. Res., 2(9), 1387-1391, (1999)

[3] S. Shahidan, H. B. Koh, A. M. S. Alansi and L. Y. Loon, Strength Development and Water Permeability of Engineered Biomass Aggregate Pervious Concrete, MATEC Web of Conf., 2-7, (2016)

[4] S. Shahidan, I. Isham, and N. Jamaluddin, A Review on Waste Minimization by Adopting in Self Compacting Concrete, MATEC Web of Conf., 1-7, (2016)

[5] M. Tiwari, S. K. Sahu, R. C. Bhangare, P. Y. Ajmal, and G. G. Pandit, Elemental characterization of coal, fly ash, and bottom ash using an energy dispersive X-ray fluorescence technique, Applied Radiation and Isotope, 90, 53-57, (2014)

[6] U. Kalapathy, A. Proctor and J. Shultz, A simple method for production of pure silica from rice hull ash, Bioresour. Technol., 73, 257-262, (2000)

[7] C.P. Faizul, C. Abdullah, B. Fazlul, Extraction of Silica from Palm Ash using Organic Acid Leaching Treatment, Key Eng. Mater., 594, 329-333, (2014)

[8] R. A. Kamarudin, A. S. Matlob, Z. Jubri and Z. Ramli, Extraction of silica and alumina from coal fly ash for the synthesis of zeolites, Proc. 3rd Int. Conf. on Energy and Environment: Advancement Towards Global Sustainability, Malacca, Malaysia 456461(2009)

[9] A. U. Abubakar and K. S. Baharudin, Tanjung Bin Coal Bottom Ash: From Waste to Concrete Material, Adv Mater. Res., 705, 163-168, (2013)

[10]A. A. Kadir, M. I. H. Hassan, and M. M. A. B. Abdullah, Investigation on Leaching Behaviour of Fly Ash and Bottom Ash Replacement in Self-Compacting Concrete, IOP Conf. Ser. Mater. Sci. Eng., IOP, 133, 1-12 (2016)

[11]J. Umeda and K. Kondoh, High-purity amorphous silica originated in rice husks via carboxylic acid leaching process, J. Mater. Sci., 43(22),7084-7090, (2008)

[12]A. Quek, W. Xu, L. Guo, and D. Wu, Heavy Metal Removal from Incineration Bottom Ash through Washing with Rainwater and Seawater, Int. J. Waste Resour., 6(1) , 2-9 (2016)

[13] A. Muhardi, A. Marto, K. A. Kassim, A. M. Makhtar, L. F. Wei, and Y. S. Lim, Engineering characteristics of Tanjung Bin coal ash, Electron. J. Geotech. Eng., 15, 1117-1129, (2010)

[14]M. L Jayaranjan, A. P Annachhatre, Precipitation of heavy metals from coal ash leachate using biogenic hydrogen sulfide generated from FGD gypsum., Water Sci. Technol., 2(67), 311-8, (2013)

[15]N. Ernida, Z. Abidin, M. Haziman, W. Ibrahim, N. Jamaluddin, K. Kamaruddin, A. Farhan Hamzah, The Strength Behavior of Self-Compacting Concrete incorporating Bottom Ash as Partial Replacement to Fine Aggregate, ARPN J. of Eng. \& App. Sci., 11(4), 2570-2575, (2016)

[16]D. B. Sarode, R. N. Jadhav, V. A. Khatik, S. T. Ingle, and S. B. Attarde, Extraction and leaching of heavy metals from thermal power plant fly ash and its admixture, Polish J. Environ. Stud., 19(6), 1325-1330, (2010) 